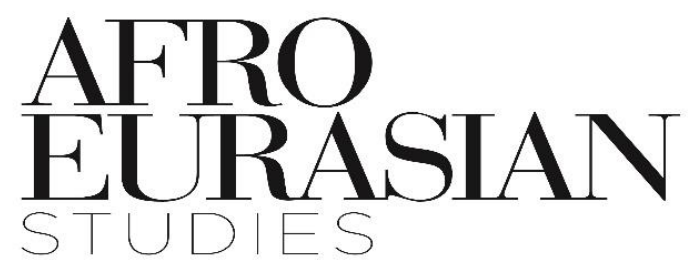

[AFES], 2019, 8 (1): 106-123

\title{
Determining the relationship between non-performing loans, economic growth, and asset size: An application in Turkish Participation Banking Sector
}

\begin{tabular}{|c||}
\hline \hline Mehmet APAN \\
Asst. Prof., Karabuk University Faculty Of Business \\
mehmetapan@karabuk.edu.tr, \\
Orcid Id: $0000-0001-9471-4810$ \\
Mehmet ISLAMOGLU \\
Assoc. Prof., Karabuk University Faculty Of Business \\
mehmetislamoglu@karabuk.edu.tr, \\
Orcid Id: $0000-0002-4416-0888$ \\
\hline \hline
\end{tabular}

Article Information

Article Types : Research Article

Received : : 10.12.2018

Accepted : 29.03 .2019

Published : 29.03.2019

Pub Date Season: March 2019

Cite as: APAN, M, İSLAMOĞLU, M. (2019). Determining the relationship between non-performing loans, economic growth, and asset size: An application in Turkish Participation Banking Sector. Afro Eurasian Studies, 8 (1), 106-123. Retrieved from http://dergipark.gov.tr/afes/issue/44214/494510

Plagiarism: This article has been reviewed by at least two referees and scanned via a plagiarism software.

Copyright ( Published by MUSIAD- Ataköy 7-8-9-10 Mah. Cobancesme E5 Yanyol Cad. No:4 Bakirkoy, 34158 Istanbul / Turkey Tel +90 (212) 3953302 Fax +90 (212) 3950001 aestudies@musiad.org.tr 


\title{
Determining the relationship between non-performing loans, economic growth, and asset size: An application in Turkish Participation Banking Sector
}

\begin{abstract}
Participation Banks are an alternative financial institution that contributes to the development and deepening of the financial system in the Turkish Banking Sector. In this study, the relationship between participation banks, nonperforming loans, gross domestic product, and asset size in the period 2005: Q1-2018: Q2 was investigated by using the co-integration, Granger causality tests and regression analysis methods. The results of the Granger causality test show that there is a one-way causality relationship between non-performing loans to gross domestic product and the gross domestic product to asset size, but there is a double causality relationship between non-performing loans and asset size. In the results of empirical analysis, a statistically significant relationship was found between both gross domestic product and asset size, and non-performing loans. In this context, it is determined that there is a negative relationship between non-performing loans and gross domestic product. On the other hand, it was determined that the asset size of the participation banking sector increased and the non-performing loans were affected in the same direction.
\end{abstract}

Keywords: Non-performing Loans, Participation Banking, Interest-Free Banking, Economic Growth, Asset size. 


\section{Introduction}

Financial institutions have also improved, depending on the development of financial markets. This development was realized by the diversity of financial instruments in the markets as well as the diversification of institutions. For the banking sector, Participation Banks or Interest-Free Banks are the new institutions of the financial markets. Unlike conventional banks, participation banks work with a system based on profit and loss partnership rather than interest-based transactions. According to the principle of this study, Participation banks, established first in 1984 under the name of the Private Finance Institution (ÖFK) in Turkey and in 2005 they were officially incorporated into the banking law by taking the name of the bank (Kartal \& Demir, 2017, s. 90). The public established Vakıf Participation Bank, Ziraat Participation bank in Turkey and supported the participation banks sector with the power of the state in the sector. In addition, studies have been initiated in the Turkish banking sector to enable conventional banks to open an interest-free banking window. As of year-end 2017, Participation banking sub-sector has an asset size of $4.91 \%$, a profit-loss participation fund (deposit) share of $6.12 \%$ and a fund (Credit) share of $4.97 \%$ in the Turkish banking sector (TKBB, 2018).

In this study, it is aimed to examine the relationship between participation banking sector (non-performing) loans, economic development and asset size. In the first chapter, studies examining the non-performing loans in banking literature are included. The second section describes data, methods and empirical analyses. The third part summarizes the findings and results of the study.

\section{1- Literature Review}

There are many studies in the banking literature that examine the nonperforming loans. Some of these studies are summarized in chronological order below.

Espinoza and Prasad (2010) analyzed the data of 80 banks in the Gulf Cooperation Organization (GCO) member countries for the period of 19952008 with dynamic panel method. In the study, it has been determined that the cumulative effect of macroeconomic shocks on non-performing loans for a three-year period is really large, and that banks' risk-taking and effectiveness levels are related to future non-performing loans.

The follow-up levels of loans in the Turkish Banking Sector have been analyzed comparatively according to the 2001 and 2008 crises by Tanınmış-Yücememiş 
and Sözer (2010). In this study, it was determined that the non-performing loan rate in Turkey increased at a limited level compared to the 2001 crisis in the 2008 crisis, but it was a lower level compared to many European Union (EU) countries.

In Italy, 1990:Q1-2010:Q2 period data and macroeconomic determinants of the quality of loans of banks were analyzed in terms of household and corporate loans by Bofondi and Roplele (2011). It has been determined that the quality of loans granted to households and companies can be explained by factors such as the general state of the economy, borrowing costs and debt burden, and changes in macroeconomic conditions generally affect the quality of credit as a result of delay.

Koyuncu and Saka (2011) analyzed the 1986-2008 data with multiple regression methods in order to determine the impact of monitored loans on private sector loans and investments in Turkey. In empirical analysis, subsequent loans have a mitigation effect on domestic loans and investments provided to the private sector.

A model has been proposed by Tanınmış-Yücememiş and Sözer (2011) for the monthly estimation of non-performing rate of credit for the Turkish banking sector. Even though there is a deterioration in economic conditions in the coming periods due to good management of non-performing loans, the increase in non-performing loans is estimated to be relatively limited.

Determinants of non-performing loans in the Greek banking sector; consumer loans, commercial loans and mortgage loans were analyzed with dynamic panel data methods by Louzis, Vouldisa and Metaxas (2012). It was determined that the non-performing loans could be explained by the variables of Gross Domestic Product (GDP), unemployment, interest rates, public debts and management quality.

Macit and Keçeli (2012) examined the macroeconomic and micro factors that determine the rate of non-performing loans for Turkish Participation banks with the period 2005-2011 data. In the study, it is determined that the ratio of nonperforming loans is lower in banks with high ratio of loans to total assets and the asset size has a negative effect on non-performing loans ratio. In addition, the decline in GDP growth both in the same period and with a delayed increase the ratio of non-performing loans, and the exchange rate level and inflation rate did not have a significant effect on the non-performing loans ratio. On the other hand, it was determined that the increase in unemployment rate had a significant effect on non-performing loans. 
Saba, Kouser and Azeem (2012) examined the factors affecting the rate of nonperforming loans of the United States (USA) Banking System. The study found that real GDP per capita, inflation and total credits had a significant impact on the non-performing loans, but the coefficient values of the independent variables were not very high.

It was determined by Zeng (2012) that micro and macro-economic factors were effective on the level of non-performing loans in the Chinese banking system.

It was attempted to determine the determinants of non-performing loans with the 2004-2008 period data of 85 banks in Italy, Greece and Spain by Messai and Jouini (2013). In this study, GDP growth rate as macroeconomic variables, unemployment rate, real interest rate, asset specificity as bank specific variables, change in loans and change in non-performing loans ratio were used. The study found that there was a negative correlation between the GDP growth rate and non-performing loans. On the other hand, it has been determined that there is a positive relationship between the non-performing loans and the active profitability, unemployment rate, the ratio of loan provision expenses to the total loans and the real interest rate variables.

The relationship between macroeconomic factors and bank specific factors and non-performing loan ratio was analyzed by Vatansever and Hepşen (2013) using the January 2007-March 2013 period data. Linear regression models and cointegration analysis in empirical analysis methods were used. In the study, It was determined that the borrowing ratio, loans / asset ratio, real sector confidence index, consumer price index, EURO exchange rate, USD exchange rate, change in money supply, interest rate, change in national income, change in the national income of the Euro Zone and Standard \& Poor's 500 stock market index variables were not effective on non-performing loans. On the other hand, the index of industrial production, Istanbul Stock Exchange (ISE) - 100 Index, the banks ' ineffectiveness rate variables have been determined to be negatively effective on non - performing loans. In addition, the unemployment rate, equity profitability and capital adequacy rate variables have been found to be positively effective on the non - performing loans.

The 2003-2012 period data of 16 Tunisian banks were analyzed using the dynamic panel data method by Abid, Ouertani and Zouari-Ghorel (2014). The study model examined the potential impact of GDP, inflation, interest rate and bank-specific variables on the quality of loans of households. In the study, it was determined that the level of non-performing loans of the households could 
not be explained with the level of GDP, inflation, interest rates, however, nonperforming loans could be explained by the poor management quality.

Škarıca (2014) examined the 2007: Q3-2012: Q3 period data of the banking sector of the 7 Central and Eastern European countries through the analysis method of the panel. In this context, banking data from Bulgaria, Croatia, Czech Republic, Hungary, Latvia, Romania and Slovakia were analyzed. It was determined that the economy entered slowdown process with increase in the rate of non-performing loans and the increase in the rate of non-performing loans had a statistically significant effect on the national income, unemployment and inflation.

The determinants affecting the level of non-performing loans of 75 countries have been examined by Beck, Jakubik and Piloui (2015). Non-performing loans, real GDP growth, stock prices, exchange rate and lending interest rate are used as variables. In the research, it was determined that the effect of exchange rate on foreign exchange loans depends on the scope of foreign exchange credits and share prices in countries with large trading volume have a higher effect on GDP.

Central, Eastern and South Western European Countries (Albania, Bosnia and Herzegovina, Bulgaria, Croatia, Hungary, Lithuania, Montenegro, Macedonia, Romania, Serbia and Slovenia)'s 2006-2013 period and non-performing loans affecting variables were analyzed by Tanasković and Jandrić (2015). The logarithm of the non-performing loans ratio was taken for the analysis and the data set was analyzed with a static panel model approach. In this study, there is a negative correlation between increases in GDP and the rate of non-performing loans; it was found that there was a positive relationship between GDP and foreign currency loans, exchange rate level and non-performing loan ratio. On the other hand, the effect of inflation rate on non-performing loans was statistically insignificant.

After 2001 financial crisis in Turkey, it is aimed to determine the factors that influence the banks non-performing loan rates by Abdioğlu and Aytekin (2016). 2002-2014 period data was used for this purpose. In the analysis of the data set, system GMM and difference GMM methods were used from GMM (Generalized method of moments) methods. In this study, it was determined that the non-performing loans rate in the previous period, net interest margin, capital adequacy and payment power had a negative impact on the non-performing loans. On the other hand, it has been determined that there is a positive correlation between the interest rate, credit/deposit ratio, inefficiency and 
activity variables applied to loans and the non-performing loans. The study was consistent with the ethical hazard hypothesis and the bad management hypothesis, but it was found that there were conflicting results with the variation hypothesis.

Beaton, Myrvoda and Thompson (2016) aimed to determine the impact of the deterioration of the banking systems of the Eastern Caribbean Monetary Union countries on economic activities. For empirical analysis of the study, 1996:Q12015:Q4 period data were used. In empirical analyses, macroeconomic and bank-specific factors were determined to have an effect on the deterioration of the assets quality of the banks. In this context, a low credit disbursement policy for the construction sector and households for the purpose of high profitability has been determined to be effective in the realization of the following loans at a low level. On the other hand, it has been determined that the rate of nonperforming loans of foreign capital banks is lower than those of domestic capital banks.

Morakinyo and Sibanda (2016) examined the relationship between the nonperforming loans and economic variables in Nigeria with the ARDL (Autoregressive Distributed lag) model. The data for the quarter-term 19982014 period were used for the study. It was found that the variables in the research model were statistically significant in the long-term. In addition, it has been determined that non-performing loans have a negative impact on economic growth, but bank loans have a direct impact on economic growth.

Us (2016) examined the determinants of the non-performing loans in the Turkish banking sector before and after the global crisis. In this study, the variables of continuity, capital adequacy, profitability, credit supply, inefficiency and bank size are bank-specific determinants; growth, inflation, exchange rate and policy interest are included in the model as macroeconomic variables. In addition, the model of the global crisis has taken place as a dummy variable. In the results of empirical analysis, it was determined that the nonperforming loans were largely determined by bank-specific variables in the precrisis period and the effect of these variables was decreased in the post-crisis period.

It is aimed to identify the factors that determine the rate of non-performing loans in Turkey by Yüksel (2016). For this purpose, macroeconomic and macroeconomic variables were used for the period of 1988-2014. The data set has been analyzed by the MARS method. In the study, it was determined that the increase in USD rate increased the ratio of non-performing loans of banks 
and the increase in the interest rates of banks and the growth rate of the country had a decreasing effect on the ratio of non-performing loans.

The model proposal was developed by Kartal and Demir (2017) to transfer problematic loans of Participation banks to asset management companies in Turkey.

The effects of non-performing loans on financial stability was examined in comparison with the 2000-2016 period data in Turkey and Saudi Arabia by Polat (2018). In the study, for Turkey, it was found that there is a positive relationship between GDP, market capitalization, inflation rate and nonperforming loans ratio. However, for Saudi Arabia, although it was determined that there was a positive relationship between inflation rate, debt, market capitalization, money supply and non-performing loans ratio, it was determined that there is a negative relationship between unemployment rate, transparency variable and non-performing loans ratio.

Tekşen and Çelik (2018) examined the effect of the loan types on the loan rate on non-performing loans ratio by using panel data analysis methodology for the period 2006-2016 of 10 Turkish deposit banks. In this study, it was determined that there was a negative correlation between housing and commercial vehicle loans and non-performing loans ratio, whereas there was a positive correlation between the non-performing loans ratio and vehicle loans ratio. In addition, it was determined that inflation, the ratio of non-performing loans in previous period, and asset size variables had a significant and positive effect on the ratio of non-performing loans, but the crisis variable had a significant and negative effect on non-performing loans ratio.

\section{2- Data, Method and Empirical Analysis}

\section{Data}

In this study, the relationship between non-performing loan ratio and gross domestic product and asset size was investigated. In determining this relationship, quarterly data of Participation banking sector were used. In this study, the non-performing loan ratio were regressed by taking the difference between the natural logarithm gross domestic product and the asset size variables. $\Delta$ in the model represents the difference process notation for variables. Non-performing loans ratio and asset size data were obtained from the Banking Regulation and Supervision Agency (BDDK) www.bddk.gov.tr.address. The amount of Gross domestic product data is obtained from www.tcmb.gov.tr of the Central Bank of the Republic of Turkey 
(TCMB) Electronic Data System (EVS). In the Study, Eviews 9 package program was used for empirical analyses. Information about the variables used for research is shown in Table 1.

Table 1: Research Variables

\begin{tabular}{|c|c|c|c|}
\hline Abbreviations & Variable Names & Source & Data Range \\
\hline$\triangle \mathrm{NPLR}$ & NPL Ratios & www.bddk.gov.tr & $\begin{array}{l}\text { 2005Q1- } \\
\text { 2018Q2 } \\
\text { 2005Q1- }\end{array}$ \\
\hline$\Delta$ LOGGSYIH & Gross Domestic Product & www.tcmb.gov.tr & $\begin{array}{l}\text { 2018Q2 } \\
\text { 2005Q1- }\end{array}$ \\
\hline$\triangle \mathrm{AKB}$ & Active Size & www.bddk.gov.tr & 2018Q2 \\
\hline
\end{tabular}

\section{Method}

In the study, it is investigated whether there is a statistically significant relationship between the NPL ratio of the Participation Banking Sector, GDP and the asset size of the Participation Banking Sector. For this purpose, it is necessary to determine whether the series contain unit roots. In order to determine the stability of the research variables, a unit root test was performed with the Phillips-Perron test. Then, regression estimation was performed with the smallest squares method to test whether there is a statistically significant correlation between the series. In order to determine whether this relationship exists in the long-term, Johansen (1991) co-integration test was applied for the series. The Johansen co-integration test is a test based on the VAR (Vector Auto-regressive) analysis. Therefore, VAR analysis was performed by Hall (1991) to determine the appropriate delay length before Johansen co-integration test. In the case that the variables subject to analysis are not stable at the same level, the differences have been taken and the differences have been determined to be stable at the same degree. Since there is a loss of value in the realized series, co-integration analysis is an analysis based on the original values. After the Johansen co-integration test, Granger (1969) causality test was applied to determine the relationship between variables and determine the direction of the relationship if any relationship exists.

\section{Empirical Analysis}

Because the data set of variables to be used in the Analyses is a time series, the data must be static. Working with non-stationary time series leads to a false 
regression problem. In this case, the results obtained from the regression analysis do not reflect the actual relationship (Gujarati, 1999, p. 726). In the study, the stability and stability levels of the variables were tested by PhillipPerron unit root test. According to the results of the Phillip-Perron unit root test, the difference process was applied because all NPLR, GDP and AKB series contain unit root values and it was observed that the primary difference was stagnated. In addition, a logarithmic transformation has been implemented in the GDP series. After these transformations, Phillips-Perron Unit root test results of the research variables are presented in Table 2.

Table 2: Phillips-Perron test statistic results

\begin{tabular}{|c|c|c|c|c|c|c|c|}
\hline \multirow{3}{*}{\multicolumn{2}{|c|}{$\begin{array}{l} \\
\text { Phillips-Perron } \\
\text { test statistic }\end{array}$}} & \multicolumn{2}{|l|}{$\Delta$ NPLR } & \multicolumn{2}{|c|}{$\Delta$ LOGGSYIH } & \multicolumn{2}{|l|}{$\triangle \mathrm{AKB}$} \\
\hline & & $\begin{array}{|ll|}\text { Adj. } & \text { t- } \\
\text { Stat } & \\
\end{array}$ & Prob.* & \begin{tabular}{|ll} 
Adj. & t- \\
Stat & \\
\end{tabular} & Prob.* & $\begin{array}{l}\text { Adj. } \quad \mathrm{t}- \\
\text { Stat }\end{array}$ & Prob.* \\
\hline & & $\begin{array}{l} \\
6.434144 \\
\end{array}$ & \begin{tabular}{|l|}
0.000 \\
0 \\
\end{tabular} & $\begin{array}{l}- \\
1.909200 \\
\end{array}$ & \begin{tabular}{|l|}
0.000 \\
0 \\
\end{tabular} & 7.192 .463 & $\begin{array}{l}0.000 \\
0 \\
\end{array}$ \\
\hline \multirow{3}{*}{$\begin{array}{l}\text { Test } \\
\text { critica } \\
1 \\
\text { values }\end{array}$} & $1 \%$ level & \multicolumn{2}{|l|}{ - 4.144584} & $-\overline{4.144584}$ & & \multicolumn{2}{|l|}{-4.144584} \\
\hline & $5 \%$ level & & \multicolumn{2}{|l|}{3.498692} & \multicolumn{2}{|l|}{3.498692} \\
\hline & $\begin{array}{l}10 \% \text { leve } \\
1\end{array}$ & \multicolumn{2}{|l|}{-} & \multicolumn{2}{|l|}{-} & \multicolumn{2}{|l|}{$\begin{array}{l}- \\
3.178578\end{array}$} \\
\hline
\end{tabular}

After the stability of the series provided, in order to determine whether there is a statistically significant correlation between the two series, regression was performed by using the least squares method. Regression analysis is one of the tools used to define the relationship between the dependent (described) variable and the independent (explanatory) variable and to calculate the degree of this relationship (Tar1, 1999, p. 15). The regression equation describing the relationship between variables is shown in (1).

$\triangle N P L R=\alpha+\beta_{0} \Delta L O G G S Y I H+\beta_{1} \Delta A K B+u(1)$

If there is a statistically significant relationship between the variable dependent and participation banking sector's non-performing loans rate and the gross domestic product and the asset size of the participation banking sector, the direction of this relationship will be determined by regression analysis. In this 
context, the estimation results of the regression model including $\triangle$ NPLR, $\triangle$ LOGGSYIH and $\triangle \mathrm{AKB}$ variables are presented in Table 3.

Table 3: Regression Estimation Results

\begin{tabular}{|c|c|c|c|c|}
\hline $\begin{array}{l}\text { Dependent Variable } \\
\text { Method } \\
\text { Observations }\end{array}$ & $\begin{array}{l}: \triangle \mathrm{NPI} \\
: \text { Least } \\
: 53\end{array}$ & fuares & \multirow[b]{2}{*}{$\mathrm{t}$-Statistic } & \multirow[b]{2}{*}{ Prob. } \\
\hline Variable & Coefficient & Std. Error & & \\
\hline$\Delta$ LOGGSYIH & -1.90641 & 0.728223 & -2.617890 & 0.0117 \\
\hline$\triangle \mathrm{AKB}$ & $5.72 \mathrm{E}-08$ & $2.12 \mathrm{E}-08$ & 2.696937 & 0.0095 \\
\hline $\mathrm{C}$ & -0.17614 & 0.101939 & -1.727847 & 0.0902 \\
\hline$\overline{\mathrm{R}^{2}}$ & 0.187 & & & \\
\hline F-Statistics & $: 5.760$ & & & \\
\hline Adjusted $\mathrm{R}^{2}$ & $: 0.154$ & & & \\
\hline Prob (F-Statistics) & $: 0.005$ & & & \\
\hline
\end{tabular}

According to the results of the regression estimation in Table 3, it is seen that there is a statistically significant relationship between both the gross domestic product and the asset size of the participation banking sector and the nonperforming loans ratio of the participation banking sector. Within this framework, it is determined that there is a negative relationship between nonperforming loans and gross domestic product. Accordingly, the decrease in gross domestic product increases the non-performing loan ratio of the participation banking sector. On the other hand, the increase in asset size of the participation banking sector affects the non-performing loan ratio of the sector in the same direction. The relationship between $\triangle$ LOGGSIH and $\triangle \mathrm{AKB}$ variables was found to be statistically significant at the significance level of $\% 1$ (probe (F-statistic): 0.005608). The explanation power of the research model (R2) was found to be $18 \%$.

The results of the regression analysis show that there is a statistically significant relationship between the series. After this phase, the Johansen co-integration test will be applied to the series to determine whether this relationship exists in the long run. In Johansen's peer-integration analysis, the appropriate delay length of the VAR model must be determined first. For this purpose, the criteria LR (Likelihood ratio), FPE (final prediction error), AIC (Aqaike information criterion), SC (Schwarz information criterion), HQ (Hannan-Quinn information criterion) were used. Since the frequency of the series is a quarter term, the 
appropriate delay length is queried for a 4-term delay length. The most appropriate delay length for the VAR model is provided in the 4th position with the '*' mark at the maximum. For this reason, delay length was determined as 4 in other stages of co-integration analysis. The results of the analysis of the delay length are presented in Table 4.

Table 4: Delay Length Test Results

\begin{tabular}{|c|c|c|c|c|c|c|}
\hline Lag & $\log L$ & LR & FPE & AIC & $\mathrm{SC}$ & HQ \\
\hline 0 & 806.0123 & NA & $4.40 \mathrm{e}+10$ & 33.02091 & 33.13674 & 33.06485 \\
\hline 1 & $\begin{array}{l}791.5390 \\
-\end{array}$ & 26.58358 & $3.52 \mathrm{e}+10$ & 32.79751 & 33.26081 & 32.97329 \\
\hline 2 & $\begin{array}{l}763.6547 \\
-\end{array}$ & 47.80160 & $1.64 \mathrm{e}+10$ & 32.02672 & 32.83750 & 32.33433 \\
\hline 3 & $\begin{array}{l}721.2834 \\
-\end{array}$ & 67.44832 & $4.24 \mathrm{e}+09$ & 30.66463 & $31.82288^{*}$ & 31.10407 \\
\hline 4 & 706.1663 & $22.21284^{*}$ & $3.38 \mathrm{e}+09 *$ & $30.41495^{*}$ & 31.92068 & $30.98622 *$ \\
\hline $\begin{array}{l}* \text { ind } \\
\text { LR:s } \\
\text { predi } \\
\text { criter }\end{array}$ & $\begin{array}{l}\text { ates lag or } \\
\text { uential m } \\
\text { on error, } \\
\text { n, HQ:Ha }\end{array}$ & $\begin{array}{l}\text { der selected } \\
\text { odified LR } \\
\text { AIC:Akaik } \\
\text { nnan-Quinn }\end{array}$ & $\begin{array}{l}\text { y the criteri } \\
\text { st statistic } \\
\text { informatio } \\
\text { formation }\end{array}$ & $\begin{array}{l}\text { each test } \\
\text { criterion, } \\
\text { iterion }\end{array}$ & $\begin{array}{l}5 \% \text { leve } \\
\text { C:Schwar }\end{array}$ & $\begin{array}{l}\text { FPE: Final } \\
\text { information }\end{array}$ \\
\hline
\end{tabular}

Johansen benefited from two different tests, Trace and Max-Eigen value testing, to reveal the relationship between the co-integration. Accordingly, if calculated statistics are higher than the critical values, then the existence of a co-integration relationship is decided. For Trace and Max-Eigen value test results, the MAC Kinnon-Haug-Michelis (1999) $\mathrm{p}$ is below the 0.05 digit. In This context, 3 cointegration equations were found according to the appropriate delay length 4 . Multivariate co-integration Test Results are presented in Table 5. 
Tablo 5: Multivariate Cointegration Test Results

\begin{tabular}{|c|c|c|c|c|c|c|}
\hline \multirow[t]{2}{*}{ Hypothesis } & \multicolumn{3}{|c|}{ Trace Testi } & \multicolumn{3}{|c|}{ Max-Eigenvalue Testi } \\
\hline & Statistic & $\begin{array}{l}\text { Critical } \\
\text { Value }\end{array}$ & Prob.** & Statistic & $\begin{array}{l}\text { Critical } \\
\text { Value }\end{array}$ & Prob.** \\
\hline & 64.0885 & & & 30.9574 & & \\
\hline $\mathrm{r}=0^{*}$ & $\begin{array}{l}2 \\
33.1310\end{array}$ & 29.79707 & 0.0000 & $\begin{array}{l}9 \\
21.0273\end{array}$ & 21.13162 & 0.0015 \\
\hline $\mathrm{r}<=1 *$ & $\begin{array}{l}3 \\
12.1036\end{array}$ & 15.49471 & 0.0001 & $\begin{array}{l}9 \\
12.1036\end{array}$ & 14.26460 & 0.0037 \\
\hline $\mathrm{r}<=2 *$ & 4 & 38.41466 & 0.0005 & 4 & 38.41466 & 0.0005 \\
\hline
\end{tabular}

After the Johansen co-integration test, the Granger causality test was used to determine whether there is a one-way or two-way causality relationship between variables. In Granger causality test, the hypothesis is established whether the direction of causality is double-sided or single-sided. The results of the causality relationship between the research variables are shown in Table 6 .

Tablo 6: VAR Granger Causality/Block Exogeneity Wald Tests

\begin{tabular}{|c|c|c|c|c|c|c|c|c|c|c|c|}
\hline \multicolumn{4}{|c|}{$\begin{array}{l}\text { Dependent variable: } \\
\Delta \text { NPLR }\end{array}$} & \multicolumn{4}{|c|}{$\begin{array}{l}\text { Dependent variable: } \\
\Delta \text { LOGGSYIH }\end{array}$} & \multicolumn{4}{|c|}{$\begin{array}{l}\text { Dependent variable: } \\
\triangle \mathrm{AKB}\end{array}$} \\
\hline & Chi-sq & $\begin{array}{l}\mathrm{d} \\
\mathrm{f}\end{array}$ & $\begin{array}{l}\operatorname{Pr} \\
\text { b. }\end{array}$ & & Chi-sq & 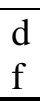 & $\begin{array}{l}\text { Pro } \\
\text { b. }\end{array}$ & & Chi-sq & $\begin{array}{l}\mathrm{d} \\
\mathrm{f}\end{array}$ & $\begin{array}{l}\text { Pro } \\
\text { b. }\end{array}$ \\
\hline$\Delta \mathrm{LOGG}$ & 2.689. & & 0. & $\Delta \mathrm{NP}$ & 1.661. & & 0.0 & & 2.151 & & 0.0 \\
\hline SYIH & $\begin{array}{l}866 \\
9.746 .\end{array}$ & 4 & $\begin{array}{l}61 \\
0 .\end{array}$ & $\begin{array}{l}\mathrm{LR} \\
\Delta \mathrm{AK}\end{array}$ & $\begin{array}{l}292 \\
5.557 .\end{array}$ & 4 & $\begin{array}{l}0 \\
0.2\end{array}$ & $\begin{array}{l}\Delta \text { NPLR } \\
\Delta \text { LOGG }\end{array}$ & $\begin{array}{l}854 \\
9.381 .\end{array}$ & 4 & $\begin{array}{l}0 \\
0.0\end{array}$ \\
\hline$\triangle \mathrm{AKB}$ & $\begin{array}{l}400 \\
1.555 .\end{array}$ & 4 & $\begin{array}{l}04 \\
0 .\end{array}$ & B & $\begin{array}{l}389 \\
2.854\end{array}$ & 4 & $\begin{array}{l}3 \\
0.0\end{array}$ & SYIH & $\begin{array}{l}906 \\
2.795 .\end{array}$ & 4 & $\begin{array}{l}5 \\
0.0\end{array}$ \\
\hline All & 648 & 8 & 05 & All & 370 & 8 & 0 & All & 389 & 8 & 0 \\
\hline
\end{tabular}

Table 6 shows the results of Granger causality test, while the independent variable $\triangle \mathrm{AKB}$ is the Granger cause of dependent variable $\triangle \mathrm{NPLR}$, the other independent variable $\Delta$ LOGGSYIH, is not the Granger cause of the dependent variable $\triangle$ NPLR. Again, $\triangle \mathrm{LOGGSYIH}$ is the Granger cause of $\triangle \mathrm{AKB}$, and there is a two-way causality relationship between $\triangle \mathrm{AKB}$ and $\triangle \mathrm{NPLR}$. The illustration of these causal relationships is presented in Figure 1. 


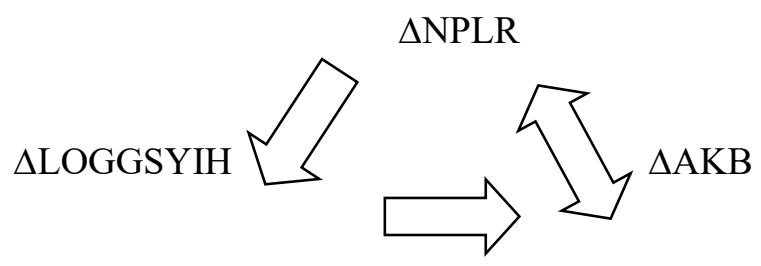

Figure 1: Granger Causality Relationship

\section{3- Result}

In this study, using co-integration test, causality test and regression analysis, the effects of gross domestic product and active size on non-performing loans for the period of 2005: Q1-2018: Q2 were examined. In the co-integration test of the study, it was determined that there was a long-term relationship between non-performing loans and gross domestic product and asset size. In the results of Granger causality test, it was determined that there is a one-way causality relationship from non-performing loans to gross domestic product and from gross domestic product to asset size, however, it is determined that there is a double causality relationship between non-performing loans and asset size.

The degree of the relationship between the variables was determined by regression analysis. In these analyzes, it was found that there was a statistically significant relationship between the gross domestic product and the asset size of the Participation banking sector and the ratio of non-performing loans in the Participation banking sector. In this context, it is determined that there is a negative relationship between non-performing loans and gross domestic product. Accordingly, the decrease in gross domestic product increases the nonperforming loan ratio of the Participation banking sector. On the other hand, it was determined that the increase in the asset size of the Participation banking sector affect the non-performing loan ratio in the same direction. 


\section{REFERENCES}

Abdioğlu, N., \& Aytekin, S. (2016). Takipteki Kredi Oranını Etkileyen Faktörlerin Belirlenmesi: Mevduat Bankaları Üzerinde Bir Dinamik Panel Veri Uygulaması. İşletme Araştırmaları Dergisi, 8(1), 538-555. (Access:www.isarder.org).

Abid, L., Ouertani, M. N., \& Zouari-Ghorbel, S. (2014). Macroeconomic and Bank-Specific Determinants of Household's Non-Performing Loans in Tunisia: a Dynamic Panel Data. Procedia Economics and Finance, (13), 58 - 68. (doi:10.1016/S2212-5671(14)00430-4).

Beaton, K., Myrvoda, A., \& Thompson, S. (2016). Non-Performing Loans in the ECCU: Determinants and Macroeconomic Impact. International Monetary Fund (Access:www.imf.org).

Beck, R., Jakubik, P., \& Piloiu, A. (2015). Key Determinants of Nonperforming Loans: New Evidence from a Global Sample. Open Economies Review, 26(3), 525-550. (doi:10.1007/s11079-015-9358-8).

Bofondi, M., \& Ropele, T. (2011). Macroeconomic determinants of bad loans: evidence from Italian banks.

Banca D'Italia Eurosistema. (Access:www.bancaditalia.it).

Espinoza, R., \& Prasad, A. (2010). Nonperforming Loans in the GCC Banking System and their Macroeconomic Effects. International Monetary Fund (Access:www.imf.org).

Granger, C.W.J. (1969). Investigating causal relation by econometric and crosssectional method, Econometrica, (37), 424-438.

Gujarati, D. N. (1999). Temel Ekonometri. (Ü. Şenesen, \& G. Günlük-Şenesen, Translation.) İstanbul: Literatür Yayınc1lı. 
Hall, S.G. (1991). The Effect of varying length VAR Models on the maximum likelihood estimates of cointegrating vectors. Scottish Journal of Political Economy, (38), 317-323.

Johansen, S. (1991). Estimation and Hypothesis Testing of Cointegration Vectors in Gaussian Vector Autoregressive Models. Econometrica, 59(6), 1551-1580.

Kartal, M. T., \& Demir, C. H. (2017). Türkiye'de Katılım Bankacılığında Sorunlu Kredilerin Varlık Yönetim Şirketlerine Satışı Üzerine Bir İnceleme ve Yöntem Önerileri. İslam Ekonomisi ve Finansı Dergisi, (1), 89-115.

Koyuncu, C., \& Saka, B. (2011). Takipteki Kredilerin Özel Sektöre Verilen Krediler ve Yatırımlar Üzerindeki Etkisi. Dumlupınar Üniversitesi Sosyal Bilimler Dergisi, (31), 113-124.

Louzis, D. P., Vouldisa, A. T., \& Metaxas, V. L. (2012). Macroeconomic and bank-specific determinants of non-performing loans in Greece: A comparative study of mortgage, business and consumer loan portfolios. Journal of Banking \& Finance, (36), 1012-1027. (doi:10.1016/j.jbankfin.2011.10.012).

Macit, F., \& Keçeli, B. (2012). Takipteki Krediler Oranını Etkileyen Faktörler: Türkiye'de Katılım Bankaları Örneği. Avrasya İncelemeleri Dergisi, (1), 151161.

MacKinnon, J., Haug, A., \& Michelis, L. (1999). Numerical Distribution Functions of Likelihood Ratio Tests for Cointegration, Journal of Applied Econometrics, 14(5), 563-577.

Messai, A. S., \& Jouini, F. (2013). Micro and Macro Determinants of Nonperforming Loans. International Journal of Economics and Financial Issues, 3(4), 852-860. (Access:www.econjournals.com). 
Morakinyo, A. E., \& Sibanda, M. (2016). Non-Performing Loans and Economic Growth in Nigeria: A Dynamic Analysis. SPOUDAI Journal of Economics and Business, 66(4), 61-81. (Access :http://spoudai.unipi.gr).

Polat, A. (2018). Macroeconomic Determinants of Non-Performing Loans: Case of Turkey and Saudi Arabia. İsletme Araştırmaları Dergisi, 10(3), 603709. (doi:10.20491/isarder.2018.495).

Saba, I., Kouser, R., \& Azeem, M. (2012). Determinants of Non Performing Loans: Case of US Banking Sector. The Romanian Economic Journal, (44), 125-136. (Access:http://www.rejournal.eu/issue/issue-44-year-xv-june-2012).

Škarıca, B. (2014). Determinants of non-performing loans in Central and Eastern European countires. financial theory and practice , 38(1), 37-59. (doi: 10.3326/fintp.38.1.2).

Tanasković, S., \& Jandrić, M. (2015). Macroeconomic and Institutional Determinants of Non-performing Loans . Journal of Central Banking Theory and Practice, (1), 47-62. (doi:10.1515/jcbtp-2015-0004).

Tanınmış-Yücememiş, B., \& Sözer, İ. A. (2010). Türk Bankacılık Sektöründe Takipteki Krediler: Mukayeseli Kriz Performansı. Avrupa Araştırmaları Dergisi, 18(1-2), 89-119.

Tanınmış-Yücememiş, B., \& Sözer, İ. A. (2011). Bankalarda Takipteki Krediler: Türk Bankacılık Sektöründe Takipteki Kredilerin Tahminine Yönelik Bir Model Uygulaması. Finansal Araştırmalar ve Çalışmalar Dergisi, 3(5), 4356.

Tarı, R. (1999). Ekonometri. İstanbul: Alfa Basım Yayım Dağıtım.

Tekşen, Ö., \& Çelik, M. (2018). Kredi Türlerinin Takipteki Krediler Oranına Etkisi: Varlık Temelli Krediler Yüksek Takipteki Krediler Oranı İçin Bir 
Kalkan M1? Muhasebe ve Finansman Dergisi, (79), 95-110. (doi:10.25095/mufad.438778).

TKBB. (2018). Türkiye Katılım Bankaları Birliği. www.tkbb.org.tr

Us, V. (2016). Determinants of Non-Performing Loans in the Turkish Banking Sector: What Has Changed After the Global Crisis? Türkiye Cumhuriyet Merkez Bankası.(Access:www.tcmb.gov.tr).

Vatansever, M., \& Hepşen, A. (2013). Determining Impacts on Non-Performing Loan Ratio in Turkey. Journal of Finance and Investment Analysis, 2(4), 119129.

Yüksel, S. (2016). Bankaların Takipteki Krediler Oranını Belirleyen Faktörler: Türkiye İçin Bir Model Önerisi. Bankacılar Dergisi, (98), 41-56.

Zeng, S. (2012). Bank Non-Performing Loans (NPLS): A Dynamic Model and Analysis in China. Modern Economy, (3), 100-110. (doi:http://dx.doi.org/10.4236/me.2012.31014).

$\underline{\text { www.tcmb.gov.tr }}$

www.bddk.gov.tr 